\title{
24. PALEOMAGNETISM OF CRETACEOUS BASALTS FROM THE EAST MARIANA BASIN, WESTERN PACIFIC OCEAN ${ }^{1}$
}

\author{
Brian P. Wallick ${ }^{2}$ and Maureen B. Steiner ${ }^{3}$
}

\begin{abstract}
Cretaceous basalts have been recovered at several Ocean Drilling Program and Deep Sea Drilling Project sites where basement of Jurassic age was predicted. Sites 800 and 802 , Leg 129, both fall in this category. We have examined the paleomagnetic properties of 25 basalt samples from Site 802 in order to establish a paleolatitude for the site at the time of basalt emplacement and to compare the results to those from Deep Sea Drilling Project Site 462. Mean natural remanent magnetization intensity for the Site 802 basalts was found to be approximately $12 \mathrm{~A} / \mathrm{m}$ consistent with typical oceanic basalts. Mean stable inclination is $-34.7^{\circ} \pm 2.2$ which implies a paleolatitude of approximately $19.4^{\circ} \mathrm{S}$. This is very similar to the paleolatitudes calculated for Site 462 basalts and suggests-along with similarities in geochemistry, magnetic properties, and projected age of Site 802 basalt emplacement-both contemporaneity of and a possible source link between the two sites.
\end{abstract}

\section{INTRODUCTION}

The search for Jurassic basement within the confines of the Jurassic Magnetic Quiet Zone has been fraught with a variety of problems, not least of which is the recovery of basalts and dolerites of an age inconsistent with that predicted from observed magnetic anomaly patterns. For example, Deep Sea Drilling Project (DSDP) Hole $462 \mathrm{~A}\left(7^{\circ} 14.5^{\prime} \mathrm{N}, 165^{\circ} 1.9^{\prime} \mathrm{E}\right)$ was drilled in the Nauru Basin just north of what was interpreted to be magnetic anomaly M26, which suggests a Late Jurassic age for the site (Larson et al., 1981). The first leg to drill the site, Leg 61, discontinued drilling after recovery of some $500+m$ of Cretaceous volcanics (Larson et al., 1981); reentry of Hole $462 \mathrm{~A}$ on Leg 89 penetrated an additional $137 \mathrm{~m}$ of early Aptian or older basalt without encountering sediments or basement rocks of the predicted Jurassic age (Moberly et al., 1986).

The drilling results of Leg 129 yielded similar results for two of three sites, Site $800\left(21^{\circ} 55.4^{\prime} \mathrm{N}, 152^{\circ} 19.4^{\prime} \mathrm{E}\right)$ in the Pigafetta Basin and Site $802\left(12^{\circ} 5.8^{\prime} \mathrm{N}, 153^{\circ} 12.6^{\prime} \mathrm{E}\right)$ in the East Mariana Basin. Of particular interest is Site 802, which was drilled in the "Jurassic Quiet Zone"- a region presumed to be older than polarity chron M33 (Handschumacher et al., 1988) and hence having a predicted age of Middle Jurassic (Lancelot et al., 1990). Drilling at this site was terminated after penetration of $44 \mathrm{~m}$ of late Aptian extrusive basalts.

Examination of the paleomagnetic parameters of the extrusive basalts from Site 802 provides an opportunity to place a paleolatitude on the site at the time of emplacement. In addition, comparison of the properties of these materials with those recovered at Site 462 in the Nauru Basin provides possible insight into the relationship between these two sites.

\section{METHODS}

A total of 25 samples were taken from fine-grained basalt cores of Hole 802A. Of 17 flow units identified on board (Shipboard Scientific Party, 1990), 13 were sampled, the remainder being either too coarsegrained or too poorly represented (Fig. 1). While the sampling statistics do not adequately negate the effects of secular variation, a sufficient

\footnotetext{
${ }^{1}$ Larson, R. L., Lancelot, Y., et al., 1992. Proc. ODP, Sci. Results, 129: College Station, TX (Ocean Drilling Program).

${ }^{2}$ Department of Earth and Atmospheric Science, Purdue University, West Lafayette, IN 47907 , U.S.A.

${ }^{3}$ Department of Geology and Geophysics, University of Wyoming, Laramie, WY 82701, U.S.A.
}

number of flow units were sampled to allow characterization of the paleomagnetic properties of this portion of the volcanic pile. Samples consisted of 2.5 -cm-diameter minicores drilled perpendicular to the drill core axis. Sampled intervals and their associated igneous unit designations are listed in Table 1.

All measurements of stepwise degmagnetization were performed using a Schonstedt SSM-1 spinner magnetometer; six spin orientations were performed on each sample in order to minimize measurement error. Demagnetization was accomplished using a Schonstedt GSD-1 single-axis alternating field (AF) demagnetizer with incremental steps carried from $2.5 \mathrm{mT}$ to a maximum of $65 \mathrm{mT}$. The majority of samples were reduced to less than $10 \%$ of their initial magnetization. Susceptibility was measured using a Bison MS-3 magnetic susceptibility bridge. All magnetic measurements are given in SI units with appropriate conversions as discussed by Shive (1986).

\section{RESULTS}

\section{Intensity of Magnetization}

Measurements of natural remanent magnetization (NRM) intensity $\left(J_{0}\right)$ yielded a range of values between 0.6 and $28.8 \mathrm{~A} / \mathrm{m}$ with an average of approximately $12 \mathrm{~A} / \mathrm{m}$. The range of values is quite similar to that observed in other oceanic basalts such as those recovered from Hole 504B (Furuta and Levi, 1983). The variation of NRM intensity with depth is shown graphically in Figure 2 and, in general, shows no systematic trend with depth over the length of the hole. Conversely, variation of NRM intensity from the mean appears to be largely a function of flow morphology and, to some extent, composition.

Three different patterns of intensity decay were noted in the stepwise demagnetization results. The first pattern is represented by a change in intensity of $<10 \%$ on the first and/or second AF demagnetization step $(2.5,5.0 \mathrm{mT})$ followed on subsequent steps by more substantial intensity drops (Fig. 3A). This type of decay was noted in 13 of the 25 samples. Median destructive field (MDF) values for these samples range from 7.3 to $12.7 \mathrm{mT}$ and average approximately 9.8 $\mathrm{mT}$. A second type of decay was marked by the removal of approximately $20 \%$ of the sample magnetic intensity upon the $2.5-\mathrm{mT}$ AF demagnetization step (Fig. 3B). Found in five samples, lower coercivity of remanence and hence lower stability is indicated. MDF values for these samples are much lower, as expected from their rapid decay, and range from 4.6 to $5.8 \mathrm{mT}$. The third type of decay (Fig. 3C) was marked by an increase in intensity at the first demagnetization step and suggests the removal of a weak, laboratory or drilling remanence vector. After these increases in intensity were recognized, 


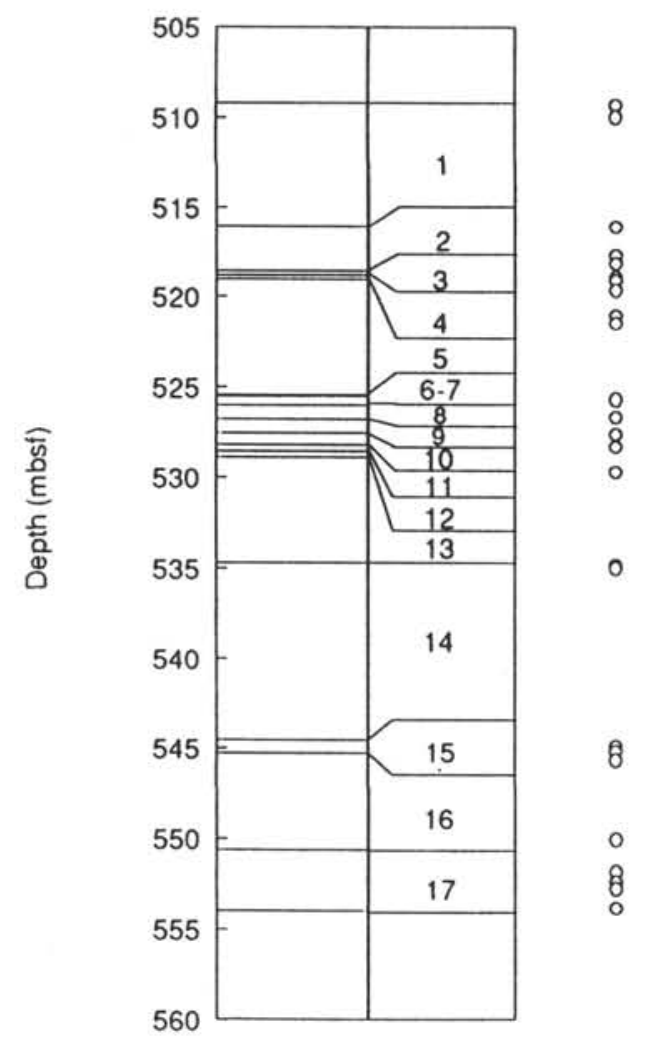

Figure 1. Basalt flow unit designation as defined by shipboard igneous petrology (Shipboard Scientific Party, 1990). The left and right columns represent the thickness and number designation of individual flow units, respectively. The open circles represent sampled intervals.

the NRM measurements of remaining, as yet undemagnetized, samples were repeated (see Appendix); these measurements showed an initial increase in intensity between the two NRM measurements similar to that seen in the single, low-field step of AF demagnetization. With no recognized consistency in direction of the vector removed, and the removal of the vector occurring with only one additional day of zero-field cleaning (i.e., short relaxation time), the weak remanence seems likely the product of storage rather than an in-situ viscous remanence.

MDF values for this previously described group ranged widely. However, when the $2.5-\mathrm{mT}$ AF step intensity was substituted for $J_{0}$, MDF values were significantly reduced in both magnitude and variance, from 8.2 to $14.1 \mathrm{mT}$ with an average value of $9.7 \mathrm{mT}$. The resulting close correspondence of the range and mean of the MDF values of these samples to those of the first-described decay pattern suggests that the AF 2.5-mT demagnetization step may be a suitable approximation for the in-situ NRM values in this group. While the values of initial NRM measurements can be seen in the compiled results of Table 1 and in the stepwise measurements listed in the Appendix, all subsequent calculations of both MDF and Koenigsberger ratio for samples exhibiting such an intensity increase (marked with a star in Table 1) will use the 2.5 -mT AF step as a substitute for the initial laboratory NRM.

\section{Susceptibility}

The susceptibility $(\chi)$ values of Site 802 basalts is between $1.75 \times$ $10^{-2}$ and $3.33 \times 10^{-2} \mathrm{SI}$, with a mean value of $2.48 \times 10^{-2} \pm 0.4 \times 10^{-2}$. Higher values of susceptibility for the flow (mean value, $2.99 \times 10^{-2}$ $\pm 0.3 \times 10^{-2}$ ) are probably associated with an increase in grain size. In general, there is a direct relationship between grain size and susceptibility (e.g., Nagata, 1961; Stacey and Banerjee, 1974) corre- sponding to the change in properties between single and multiple magnetic domains. The two flow morphologies can therefore be separated on the basis of susceptibility.

\section{Stable Inclinations}

The results of progressive AF demagnetization, vector decay curves, and declination-inclination stability were analyzed by using a combination of stereographic projection and vector-projection plots. Least squares analysis was applied to the vectors comprising stable declination-inclination values using the method developed by Kirschvink (1980). The results are given in Table 1.

Vector decay paths established during AF demagnetization (above $2.5 \mathrm{mT}$ ) were quite uniform (Fig. 4). The resultant inclinations were weighted using a method similar to that described by Ogg et al. (1991) and the mean inclination was computed for the sample suite. Since Ocean Drilling Program (ODP) drilling samples are azimuthally unoriented, the mean inclinations were calculated using the method of Kono (1980), a method which assumes that the statistics of inclination data mirrors a Fisherian distribution to magnetic directions. The basalt flows yielded a mean inclination of $-35.1^{\circ} \pm 2.5^{\circ}$, implying a paleolatitude of $19.4^{\circ} \mathrm{S} \pm 1.7^{\circ}$. The polarity of the samples was interpreted as normal and, because of negative inclination values, assumes a Southern Hemisphere origin; this inference is consistent with the southern latitude setting determined for the overlying sediments (Shipboard Scientific Party, 1990; Steiner and Wallick, this volume).

While the value given for the mean inclination provides an estimate of the paleolatitude at the time of extrusion, the basalt pile may not reflect an average of a complete secular variation cycle. The estimated value for the precision parameter $K=95.5$ from the above statistics gives an angular standard deviation of $S=8.3^{\circ}$. The predicted value for S for the 80- to 110-Ma interval (Irving and Pullaiah, 1976) was found to be $12.6^{\circ}$ for the calculated $19.4^{\circ}$ latitude, and therefore suggests that, while very similar, sampling of flows at Site 802 may be insufficient to have completely removed the effects due to secular variation. Still, the difference of less than $5^{\circ}$ between these two values of the angular standard deviation indicate the calculated paleolatitude may be considered a reasonably close approximation.

\section{DISCUSSION}

It is not possible to establish whether any structural rotation has occurred in the volcanic pile sampled at Site 802 ; indications from bedding in the overlying sedimentary rocks and from the drilling record show no evidence of severe wander in the drill hole before entry into the basalt column. Therefore, as a first approximation, the $19.4^{\circ} \mathrm{S}$ value for the paleolatitude of Site 802 at the time of the extrusion of the basalts appears reasonable even though the section does not completely cover a paleosecular variation interval. Projecting the basalt paleolatitude, along with the paleolatitudes computed for the overlying sediments, gives an age in excess of $120 \mathrm{Ma}$ (Kent and Gradstein, 1985) for the emplacement of these basalts, appreciably higher than the 114.6-Ma date determined by Pringle (this volume); this latter age is consistent with an age predicted by paleontology (Ogg, this volume). This discrepancy between the basalt paleolatitude and subsequent age projection and the sediment paleolatitude, paleontologic, and radiometric age data may be partly eliminated by assuming that a complete sampling of the volcanic pile, including a complete secular variation cycle, may give a lower overall value for the paleolatitude and hence a younger predicted age.

A reevaluation of paleontologic evidence for the age of Hole 462A interbasalt, radiolarian-bearing sediments (Shipboard Scientific Party, 1986; Schaaf, 1986) suggests deposition during the early Aptian, or approximately $118 \mathrm{Ma}$; this early Aptian age agrees with the early end of a 110 - to 120 -Ma spectrum given to the Nauru basalts by Ozima et al. (1981), while conflicting with more recent work by Pringle (this volume), who determined a 110-Ma basalt age. These data suggest age differences between Site 802 and Site 462 range from 6 m.y. based on paleontology, 
Table 1. Results of paleomagnetic analysis.

\begin{tabular}{|c|c|c|c|c|c|c|c|c|c|}
\hline $\begin{array}{c}\text { Sample } \\
(\mathrm{cm})\end{array}$ & $\begin{array}{c}\text { Flow } \\
\text { unit }\end{array}$ & $\begin{array}{l}\text { Depth } \\
\text { (mbsf) }\end{array}$ & $\begin{array}{l}J_{\text {NRM }} \\
(\mathrm{A} / \mathrm{m})\end{array}$ & $\begin{array}{c}I_{\text {NRM }} \\
\text { (degrees) }\end{array}$ & $\begin{array}{l}\text { MDF } \\
(\mathrm{mT})\end{array}$ & $\begin{array}{c}J_{s} \\
(\mathrm{~A} / \mathrm{m})\end{array}$ & $\begin{array}{c}I_{\mathrm{s}} \\
\text { (degrees) }\end{array}$ & $\underset{\left(\times 10^{-2}\right)}{\chi}$ & $Q$ \\
\hline \multicolumn{10}{|l|}{$129-802 \mathrm{~A}-$} \\
\hline as $57 \mathrm{R}-2,119$ & 1 & 500.29 & 16.5 & -1.8 & 9.9 & 3.0 & -20.6 & 2.49 & 19.8 \\
\hline $57 R-3,32$ & 1 & 509.92 & 28.5 & -28.9 & 9.9 & 11.5 & -30.0 & 2.27 & 37.6 \\
\hline $58 \mathrm{R}-1,6$ & 2 & 516.06 & 19.8 & -35.0 & 7.3 & 8.5 & -35.5 & 2.42 & 24.5 \\
\hline $58 \mathrm{R}-2,15$ & 2 & 517.65 & 3.9 & -27.9 & 5.7 & 0.6 & -35.6 & 2.86 & 4.1 \\
\hline $58 \mathrm{R}-2,61$ & 2 & 518.11 & 6.5 & -37.6 & 4.6 & 0.5 & -39.0 & 2.65 & 7.3 \\
\hline $58 \mathrm{R}-2,13$ & 4 & 518.84 & 15.6 & -32.6 & 12.7 & 8.5 & -31.1 & 2.47 & 18.9 \\
\hline $58 \mathrm{R}-3,6$ & 5 & 519.00 & 8.1 & -38.2 & 12.5 & 4.3 & -38.5 & 2.29 & 10.6 \\
\hline $58 \mathrm{R}-3,58$ & 5 & 519.58 & 11.8 & -35.8 & 4.9 & 2.4 & -36.0 & 2.77 & 12.8 \\
\hline${ }^{2} 58 \mathrm{R}-4,51$ & 5 & 521.01 & 8.9 & -17.2 & 8.6 & 2.8 & -19.3 & 2.53 & 10.5 \\
\hline${ }^{2} 58 \mathrm{R}-4,92$ & 5 & 521.42 & 0.6 & -21.9 & 8.3 & 2.9 & -21.0 & 2.47 & 0.7 \\
\hline${ }^{2} 59 \mathrm{R}-1,20$ & 7 & 525.60 & 3.4 & 25.8 & 9.8 & 1.4 & -32.7 & 1.86 & 5.5 \\
\hline a $59 \mathrm{R}-1,119$ & 8 & 526.59 & 3.8 & -46.1 & 9.1 & 1.5 & 40.8 & 1.75 & 6.5 \\
\hline${ }^{2} 59 R-2,63$ & 10 & 527.53 & 16.1 & 28.8 & 14.1 & 14.1 & -41.5 & 2.15 & 22.4 \\
\hline a $59 \mathrm{R}-2,135$ & 11 & 528.25 & 4.7 & -5.1 & 9.7 & 3.1 & -28.8 & 2.57 & 5.5 \\
\hline $59 \mathrm{R}-3,124$ & 13 & 529.64 & 12.2 & -46.9 & 9.9 & 4.1 & 47.4 & 2.28 & 16.0 \\
\hline $60 \mathrm{R}-1.7$ & 14 & 534.77 & 9.6 & 43.7 & 9.3 & 2.4 & -45.0 & 2.26 & 12.7 \\
\hline $60 \mathrm{R}-1,26$ & 14 & 534.96 & 14.8 & -42.3 & 12.3 & 0.4 & -31.3 & 2.08 & 21.2 \\
\hline $61 \mathrm{R}-1,70$ & 15 & 544.90 & 28.8 & -34.4 & 8.7 & 7.3 & -34.3 & 2.24 & 38.5 \\
\hline $61 R-1,95$ & 15 & 545.15 & 26.8 & -32.3 & 8.9 & 7.9 & -32.9 & 1.88 & 42.6 \\
\hline $61 \mathrm{R}-1,145$ & 16 & 545.65 & 17.7 & -30.9 & 8.5 & 4.4 & -31.5 & 2.65 & 20.0 \\
\hline $62 \mathrm{R}-1,92$ & 17 & 550.02 & 8.4 & -33.5 & 5.3 & 1.8 & -34.6 & 2.73 & 9.2 \\
\hline a62R-1, 121 & 17 & 551.81 & 4.6 & -20.0 & 8.2 & 1.4 & -30.0 & 3.24 & 4.3 \\
\hline $62 R-2,27$ & 17 & 552.37 & 5.4 & -22.5 & 5.8 & 0.5 & 41.5 & 3.33 & 4.8 \\
\hline $62 \mathrm{R}-2,64$ & 17 & 552.74 & 10.3 & -28.4 & 9.7 & 1.5 & -38.3 & 2.96 & 10.4 \\
\hline $62 \mathrm{R}-3,23$ & 17 & 553.83 & 11.3 & -34.3 & 4.7 & 0.8 & 44.4 & 2.70 & 12.5 \\
\hline
\end{tabular}

Notes: $J_{\mathrm{NRM}}=$ natural remanent magnetization intensity, $I_{\mathrm{NRM}}=\mathrm{NRM}$ inclination, $J_{\mathrm{s}}=$ average stable intensity, $I_{\mathrm{s}}=$ stable inclination, $\chi=$ susceptibility, $Q=$ Koenigsberger ratio.

a Samples in which the second AF step showed a rise in intensity; calculations of MDF and $Q$ for these samples are based on the second or 2.5-mT AF step as described in the text.
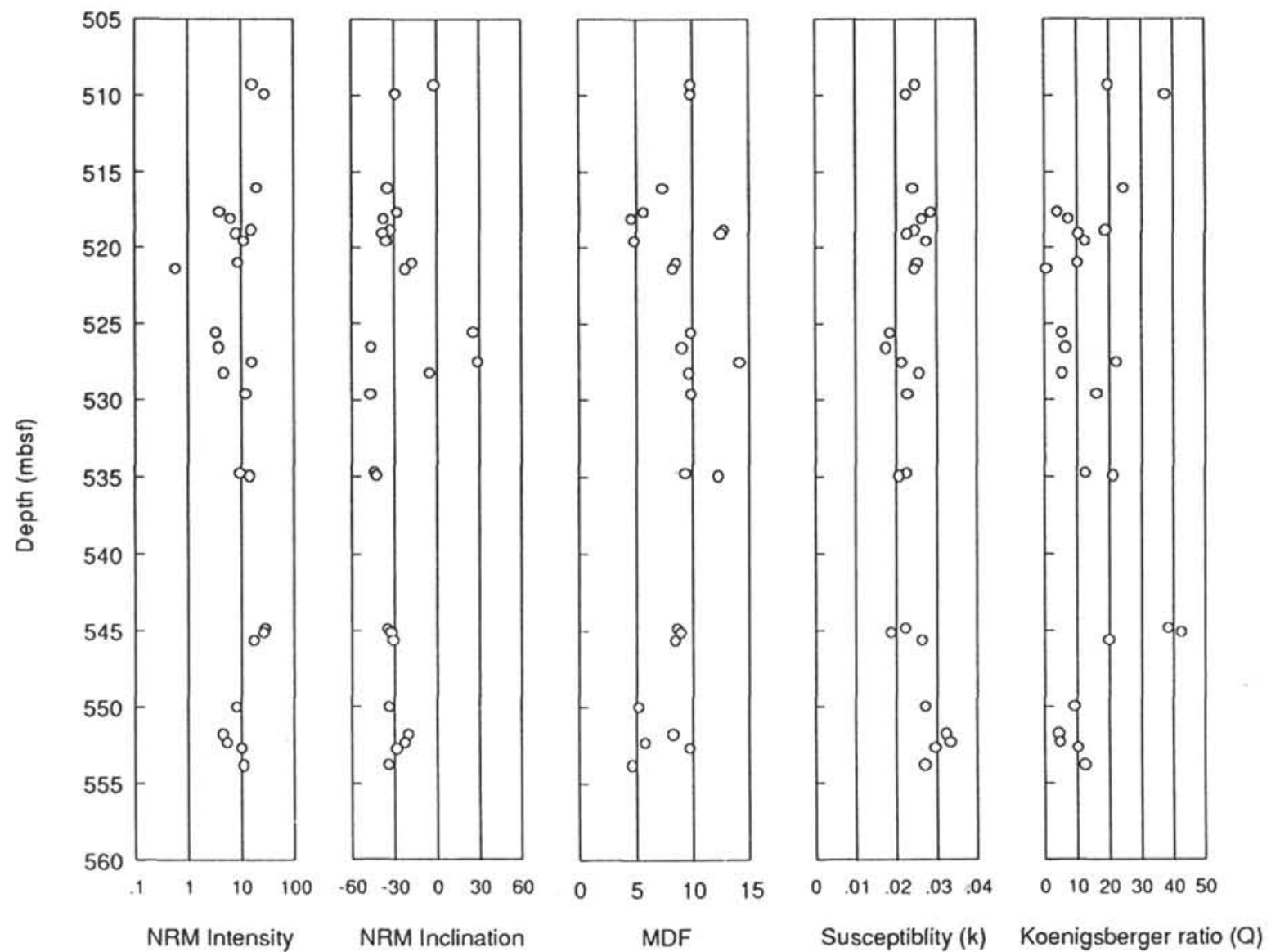

Figure 2. Changes in the magnetic parameters of NRM intensity, inclination, median destructive field (MDF), volume susceptibility, and Koenigsberger ratio with depth. 
A
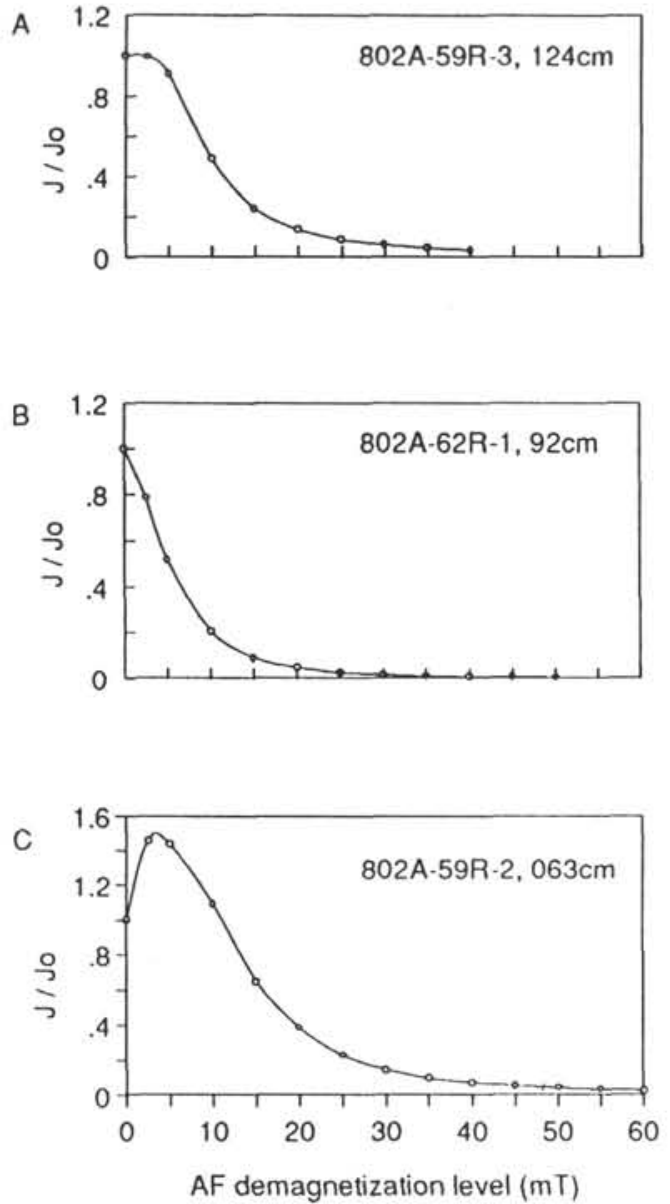

Figure 3. A-C. Demagnetization plots showing typical decay patterns of three distinct groups of samples. Values for $J$ and $J_{0}$ are provided in the Appendix under the appropriate sample number. Details are provided in the text.

approximately 4 Ma based on radiometric ages, and contemporaneity based on paleolatitude projections.

The magnetic properties of the basalt flows at the two sites show similarities with comparable average median destructive fields, susceptibilities, and NRM intensities (Shipboard Scientific Party, 1986; Steiner, 1981). Additionally, there are pronounced geochemical similarities between the two sites (Castillo, this volume). Current latitudinal separation between the two sites is approximately $5^{\circ}$; paleolatitudes of between $19.9^{\circ}$ and $20.6^{\circ}$ calculated for Hole $462 \mathrm{~A}$ (Shipboard Scientific Party, 1986) are only slightly southward of those of the present work $\left(19.4^{\circ}\right)$. It is difficult, however, to relate the results of Hole $462 \mathrm{~A}$ to this present work. From the work of Steiner (1981) and Ogg (in Shipboard Scientific Party, 1986), it is apparent that basalt flow inclinations fall into two groups: shallow $\left(<25^{\circ}\right)$ and steep $\left(>35^{\circ}\right)$. This may be due to lithology, paleosecular variation in recording of differently timed events (extrusive vs. intrusive), or, perhaps, overall crustal structure. If the estimates for the paleolatitude for Hole $462 \mathrm{~A}$ are reasonable, then it may be concluded that the two sites were formed with today's approximate separation and the missing $5^{\circ}$ of latitudinal difference is simply due to statistical sampling. If the sites are roughly contemporaneous, this would further suggest that the sites have moved along similar paths since their emplacement and may have shared a common source.

\section{CONCLUSIONS}

We offer the following conclusions regarding the Cretaceous basalts:

1. NRM intensities for these basalts averaged approximately $12 \mathrm{~A} / \mathrm{m}$, comparable to that of other oceanic basalts.

2. The average values for the median destructive field $(9.8 \mathrm{mT})$ and initial susceptibility $\left(2.4 \times 10^{-2}\right)$ suggest that, for the most part, the basalt remanence is highly stable and indicate that measured NRM intensities are probably representative of in-situ values.

3 . The paleolatitude calculated from mean paleomagnetic inclinations gives a value of $19.4^{\circ} \pm 1.7^{\circ}$, only slightly northward of the $19.9^{\circ}$ and $20.6^{\circ}$ reported for Hole $462 \mathrm{~A}$.

\section{REFERENCES}

Furuta, T., and Levi, S., 1983. Basement paleomagnetism of Hole 504B. In Cann, J. R., Langseth, M. G., Honnorez, J., Von Herzen, R. P., White, S. M., et al., Init. Repts. DSDP, 69: Washington (U.S. Govt. Printing Office), 697-703.

Handschumacher, D. W., Sager, W. W., Hilde, T.W.C., and Bracey, D. R., 1988. Pre-Cretaceous tectonic evolution of the Pacific plate and extension of the geomagnetic polarity reversal time scale with implications for the origin of the Jurassic "Quiet Zone." Tectonophysics, 155:365-380.

Irving, E., and Pullaiah, G., 1976. Reversals of the geomagnetic field, magnetostratigraphy, and relative magnitude of paleosecular variation in the Phanerozoic. Earth-Sci. Rev., 12:35-64.

Kent, D. V., and Gradstein, F. M., 1985. A Cretaceous and Jurassic geochronology. Geol. Soc. Am. Bull., 96:1419-1427.

Kirschvink, J. L., 1980. The least-squares line and plane and the analysis of palaeomagnetic data. Geophys. J. R. Astron. Soc., 62:699-718.

Kono, M., 1980. Statistics of paleomagnetic inclination data. J. Geophys. Res., $85: 3878-3882$.

Lancelot, Y., Larson, R., et al., 1990. Proc. ODP, Init. Repts., 129: College Station, TX (Ocean Drilling Program).

Larson, R. L., Schlanger, S. O., et al., 1981. Init. Repts. DSDP, 61: Washington (U.S. Govt. Printing Office).

Moberly, R., Schlanger, S. O., et al., 1986. Init. Repts. DSDP, 89: Washington (U.S. Govt. Printing Office)

Nagata, T., 1961. Rock Magnetism: Tokyo (Maruzen Co.), 350.

Ogg, J. G., Kodama, K., Wallick, B. P., 1991. Lower Cretaceous magnetostratigraphy off northwest Australia (DSDP Site 261 and ODP Site 765, Argo Abyssal Plain, and ODP Site 766, Gascoyne Abyssal Plain). In Gradstein, F. M., Ludden, J. N., et al., Proc. ODP, Sci. Results, 123: College Station, TX (Ocean Drilling Program).

Ozima, M., Saito, K., and Takigami, Y., 1981. ${ }^{40} \mathrm{Ar}-{ }^{39} \mathrm{Ar}$ Geochronological studies on rocks drilled at Holes 462 and 462A, Deep Sea Drilling Project Leg 61. In Larson, R. L., Schlanger, S. O., et al., Init. Repts. DSDP, 61: Washington (U.S. Govt. Printing Office), 701-704.

Schaaf, A., 1986. Radiolaria from deep sea drilling project Leg 89. In Moberly, R., Schlanger, S. O., et al., Init. Repts. DSDP. 89: Washington (U.S. Govt. Printing Office), 321-326.

Shipboard Scientific Party, 1986. Site 462. In Moberly, R., Schlanger, S. O. et al., 1986. Init. Repts. DSDP, 89: Washington (U.S. Govt. Printing Office), 157-212.

1990. Site 802. In Lancelot, Y., Larson, R. L., et al., Proc. ODP, Init. Repts., 129: College Station, TX (Ocean Drilling Program), 171-243.

Shive, P. N., 1986. Suggestions for the use of SI units in magnetism. Eos, 67:25

Stacey, F. D., and Banerjee, S. K., 1974. The Physical Principles of Rock Magnetism: Amsterdam (Elsevier).

Steiner, M. B., 1981. Paleomagnetism of the igneous complex, Site 462. In Larson, R. L., Schlanger, S. O., et al., 1981. Init. Repts. DSDP, 61: Washington (U.S. Govt. Printing Office), 717-730.

Date of initial receipt: 13 June 1991

Date of acceptance: 30 January 1992

Ms 129B-134 

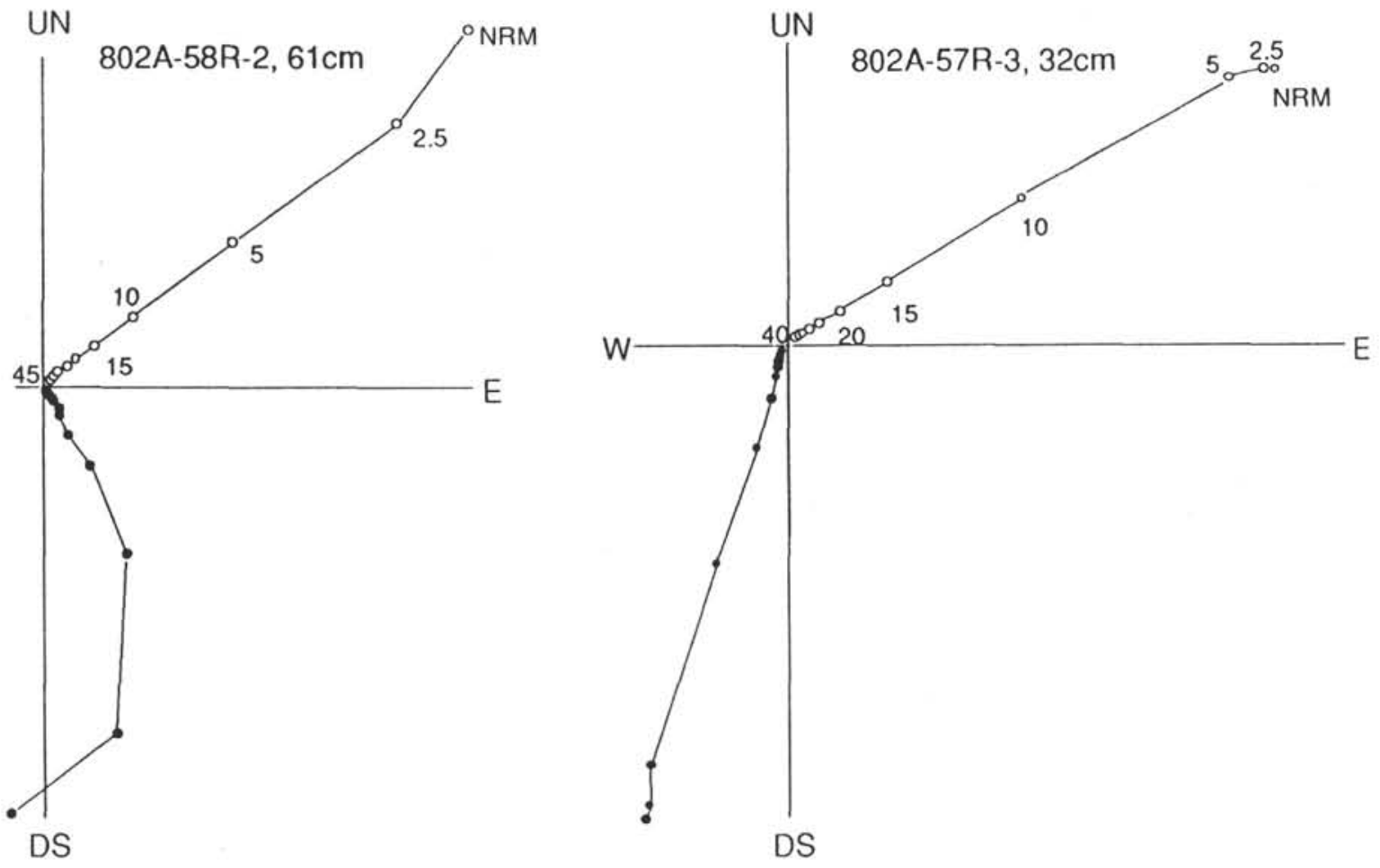

Figure 4. Zijderveld vector plots of samples illustrating the uniform decay of vectors typical of most samples analyzed in this set. 
APPENDIX

\begin{tabular}{|c|c|c|c|c|c|c|c|c|c|}
\hline $\begin{array}{l}\text { Sample } \\
(\mathrm{cm})\end{array}$ & $\begin{array}{c}\text { AF step } \\
\text { (Oe) }\end{array}$ & $\begin{array}{c}\text { Declination } \\
\text { (degrees) }\end{array}$ & $\begin{array}{l}\text { Inclination } \\
\text { (degrees) }\end{array}$ & $\begin{array}{c}\text { Intensity } \\
(\mathrm{A} / \mathrm{m})\end{array}$ & $\begin{array}{l}\text { Sample } \\
(\mathrm{cm})\end{array}$ & $\begin{array}{c}\text { AF step } \\
\text { (Oe) }\end{array}$ & $\begin{array}{l}\text { Declination } \\
\text { (degrees) }\end{array}$ & $\begin{array}{l}\text { Inclination } \\
\text { (degrees) }\end{array}$ & $\begin{array}{c}\text { Intensity } \\
(\mathrm{A} / \mathrm{m})\end{array}$ \\
\hline \multirow[t]{13}{*}{$802 \mathrm{~A}-57 \mathrm{R}-2,119$} & 0 & 98.2 & -1.8 & 16.4545 & & 25 & 208.4 & -37.6 & 8.0364 \\
\hline & 25 & 97.2 & -20.1 & 20.0909 & & 50 & 208.3 & -38.0 & 7.9273 \\
\hline & 50 & 97.5 & -20.7 & 18.1818 & & 100 & 209.1 & -36.5 & 5.5636 \\
\hline & 100 & 97.1 & -21.3 & 7.9909 & & 150 & 210.2 & -35.6 & 2.5182 \\
\hline & 150 & 96.9 & -21.7 & 2.8091 & & 200 & 210.5 & -32.6 & 1.2273 \\
\hline & 200 & 96.6 & -21.9 & 1.2909 & & 250 & 211.7 & -29.1 & 0.6100 \\
\hline & 250 & 115.6 & -27.9 & 0.5527 & & 300 & 212.2 & -24.6 & 0.3236 \\
\hline & 300 & 96.6 & -22.6 & 0.3909 & & 350 & 211.8 & -21.4 & 0.1982 \\
\hline & 350 & 96.1 & -25.2 & 0.2436 & & 400 & 214.0 & -19.8 & 0.1236 \\
\hline & 400 & 96.0 & -46.7 & 0.0973 & & 450 & 224.5 & -25.5 & 0.0689 \\
\hline & 450 & 98.2 & -26.7 & 0.1036 & & & & & \\
\hline & 500 & 94.2 & -34.1 & 0.0768 & $802 \mathrm{~A}-58 \mathrm{R}-3,58$ & 0 & 219.7 & -35.8 & 11.8182 \\
\hline & & & & & & 25 & 219.9 & -35.9 & 10.6364 \\
\hline \multirow[t]{13}{*}{$802 \mathrm{~A}-57 \mathrm{R}-3,32$} & 0 & 197.3 & -28.9 & 28.4545 & & 50 & 220.5 & -36.9 & 5.7273 \\
\hline & 25 & 196.9 & -29.6 & 28.0909 & & 100 & 220.8 & -37.0 & 2.2636 \\
\hline & 50 & 197.5 & -30.7 & 26.1818 & & 150 & 220.4 & -37.1 & 1.1727 \\
\hline & 100 & 197.0 & -31.7 & 13.9091 & & 200 & 218.9 & -37.6 & 0.7091 \\
\hline & 150 & 196.9 & -32.0 & 6.0000 & & 250 & 218.9 & -37.1 & 0.4491 \\
\hline & 200 & 195.7 & -31.6 & 3.2000 & & 300 & 220.8 & -36.6 & 0.2827 \\
\hline & 250 & 195.8 & -31.5 & 1.9364 & & 350 & 220.8 & -36.6 & 0.1991 \\
\hline & 300 & 195.3 & -31.6 & 1.3273 & & 400 & 218.4 & -36.6 & 0.1345 \\
\hline & 350 & 194.8 & -31.8 & 0.9727 & & 450 & 219.3 & -41.2 & 0.0973 \\
\hline & 400 & 194.2 & -31.4 & 0.7255 & & & & & \\
\hline & 450 & 194.2 & -31.6 & 0.5600 & $802 A-58 R-4,51$ & 0 & 180.3 & -17.2 & 8.8636 \\
\hline & 500 & 193.3 & -32.2 & 0.4445 & & 25 & 186.5 & -19.3 & 9.0636 \\
\hline & & & & & & 50 & 186.7 & -19.4 & 7.6818 \\
\hline \multirow[t]{12}{*}{$802 A-58 R-1,6$} & 0 & 280.1 & -35.0 & 19.8182 & & 100 & 186.5 & -19.9 & 3.3091 \\
\hline & 25 & 279.8 & -35.3 & 19.1818 & & 150 & 186.5 & -20.0 & 1.2909 \\
\hline & 50 & 281.3 & -36.3 & 13.9091 & & 200 & 186.4 & -19.4 & 0.6364 \\
\hline & 100 & 281.6 & -36.1 & 5.3636 & & 250 & 186.6 & -19.3 & 0.3482 \\
\hline & 150 & 275.7 & -35.5 & 2.4182 & & 300 & 186.3 & -19.3 & 0.2036 \\
\hline & 200 & 282.0 & -36.1 & 1.4545 & & 350 & 185.6 & -20.2 & 0.1182 \\
\hline & 250 & 282.9 & -38.0 & 1.0545 & & 400 & 189.1 & -25.7 & 0.0623 \\
\hline & 300 & 280.9 & -35.2 & 0.6582 & & & & & \\
\hline & 350 & 282.7 & -35.5 & 0.4773 & $802 A-58 R-4,92$ & 0 & 321.9 & -21.9 & 0.5773 \\
\hline & 400 & 282.3 & -14.1 & 0.2782 & & 25 & 291.9 & -21.4 & 14.5455 \\
\hline & 450 & 275.5 & -32.4 & 0.2400 & & 50 & 289.9 & -21.0 & 11.8182 \\
\hline & & & & & & 100 & 289.3 & -21.3 & 4.8818 \\
\hline \multirow[t]{12}{*}{ 802A-58R-2. 15} & 0 & 228.2 & -27.9 & 3.8636 & & 150 & 289.0 & -22.1 & 1.8727 \\
\hline & 25 & 225.5 & -32.0 & 3.2182 & & 200 & 289.5 & -22.0 & 0.8809 \\
\hline & 50 & 226.5 & -35.7 & 2.0818 & & 250 & 238.8 & -6.6 & 0.2909 \\
\hline & 100 & 226.3 & -37.2 & 0.9727 & & 300 & 286.0 & -22.7 & 0.2700 \\
\hline & 150 & 225.6 & -38.5 & 0.5064 & & 350 & 288.6 & -20.9 & 0.1691 \\
\hline & 200 & 225.9 & -36.3 & 0.2727 & & 400 & 286.9 & -22.8 & 0.1091 \\
\hline & 250 & 229.7 & -40.0 & 0.1400 & & & & & \\
\hline & 300 & 220.6 & -41.7 & 0.1000 & $802 \mathrm{~A}-59 \mathrm{R}-1,20$ & 0 & 95.4 & 25.8 & 3.3545 \\
\hline & 350 & 221.6 & -39.8 & 0.0623 & & 25 & 35.0 & -4.5 & 6.6091 \\
\hline & 400 & 210.0 & -51.8 & 0.0377 & & 50 & 46.5 & -26.3 & 5.2909 \\
\hline & 450 & 238.6 & -40.3 & 0.0359 & & 100 & 50.8 & -33.0 & 3.2364 \\
\hline & & & & & & 150 & 52.5 & -34.4 & 2.2909 \\
\hline \multirow[t]{13}{*}{$802 \mathrm{~A}-58 \mathrm{R}-2,61$} & 0 & 184.2 & -37.6 & 6.4727 & & 200 & 51.8 & -35.1 & 1.7818 \\
\hline & 25 & 167.5 & -36.7 & 5.2636 & & 250 & 52.9 & -34.3 & 1.3455 \\
\hline & 50 & 153.7 & -37.7 & 2.8545 & & 300 & 52.2 & -35.4 & 1.0727 \\
\hline & 100 & 150.5 & -39.1 & 1.4091 & & 350 & 51.6 & -35.5 & 0.8764 \\
\hline & 150 & 150.9 & -39.2 & 0.8191 & & 400 & 51.3 & -37.2 & 0.7136 \\
\hline & 200 & 148.3 & -39.6 & 0.5227 & & 450 & 55.0 & -36.5 & 0.5509 \\
\hline & 250 & 147.2 & -38.0 & 0.3927 & & 500 & 53.4 & -35.2 & 0.4509 \\
\hline & 300 & 147.9 & -39.5 & 0.2373 & & 550 & 67.9 & -24.9 & 0.2973 \\
\hline & 350 & 146.2 & -38.1 & 0.1809 & & 600 & 49.8 & -31.9 & 0.3027 \\
\hline & 400 & 149.0 & -42.3 & 0.1382 & & & & & \\
\hline & 450 & 150.3 & -43.4 & 0.0839 & $802 \mathrm{~A}-59 \mathrm{R}-1,119$ & 0 & 107.3 & -46.1 & 3.8364 \\
\hline & 500 & 155.7 & -48.3 & 0.0630 & & 25 & 343.0 & -34.8 & 11.2727 \\
\hline & & & & & & 50 & 342.7 & -38.0 & 9.0909 \\
\hline 802A-58R-2, 134 & 0 & 247.3 & -32.6 & 15.5455 & & 100 & 341.3 & -40.6 & 4.8182 \\
\hline & 25 & 247.9 & -30.9 & 15.5455 & & 150 & 341.9 & -40.8 & 2.8727 \\
\hline & 50 & 248.2 & -31.0 & 15.1818 & & 200 & 342.4 & -40.5 & 2.0273 \\
\hline & 100 & 248.5 & -30.7 & 10.8182 & & 250 & 342.5 & -40.6 & 1.5727 \\
\hline & 150 & 247.4 & -30.8 & 5.2364 & & 300 & 342.9 & -40.4 & 1.2545 \\
\hline & 200 & 246.8 & -30.3 & 2.6364 & & 350 & 342.6 & -40.6 & 1.0455 \\
\hline & 250 & 246.2 & -29.0 & 1.3727 & & 400 & 343.0 & -40.3 & 0.8518 \\
\hline & 300 & 245.6 & -27.8 & 0.7791 & & 450 & 343.0 & -39.9 & 0.7255 \\
\hline & 350 & 245.0 & -26.6 & 0.4827 & & 500 & 344.3 & -38.9 & 0.5927 \\
\hline & 400 & 244.8 & -25.4 & 0.3118 & & 550 & 343.1 & -39.5 & 0.4964 \\
\hline & 450 & 243.6 & -25.9 & 0.2091 & & 600 & 343.5 & -40.2 & 0.4127 \\
\hline & 500 & 244.4 & -25.9 & 0.1491 & & & & & \\
\hline & & & & & $802 \mathrm{~A}-59 \mathrm{R}-2,63$ & 0 & 217.4 & 28.8 & 16.0909 \\
\hline $802 \mathrm{~A}-58 \mathrm{R}-3,6$ & 0 & 208.2 & -38.2 & 8.1091 & & 25 & 343.6 & -41.0 & 23.4545 \\
\hline
\end{tabular}

Appendix (continued). 
Appendix (continued)

\begin{tabular}{|c|c|c|c|c|c|c|c|c|c|}
\hline $\begin{array}{l}\text { Sample } \\
(\mathrm{cm})\end{array}$ & $\begin{array}{l}\text { AF step } \\
(\mathrm{Oe})\end{array}$ & $\begin{array}{c}\text { Declination } \\
\text { (degrees) }\end{array}$ & $\begin{array}{l}\text { Inclination } \\
\text { (degrees) }\end{array}$ & $\begin{array}{l}\text { Intensity } \\
(\mathrm{A} / \mathrm{m})\end{array}$ & $\begin{array}{c}\text { Sample } \\
(\mathrm{cm})\end{array}$ & $\begin{array}{l}\text { AF step } \\
(\mathrm{Oe})\end{array}$ & $\begin{array}{c}\text { Declination } \\
\text { (degrees) }\end{array}$ & $\begin{array}{c}\text { Inclination } \\
\text { (degrees) }\end{array}$ & $\begin{array}{c}\text { Intensity } \\
(\mathrm{A} / \mathrm{m})\end{array}$ \\
\hline & 50 & 343.4 & -40.9 & 23.0909 & & 300 & 288.1 & -36.7 & 0.6564 \\
\hline & 100 & 343.8 & -41.0 & 17.5455 & & 350 & 289.4 & -36.6 & 0.4482 \\
\hline & 150 & 344.0 & -40.6 & 10.4545 & & 400 & 289.8 & -37.3 & 0.3245 \\
\hline & 200 & 345.2 & -39.6 & 6.1818 & & 450 & 292.5 & -37.1 & 0.2445 \\
\hline & 250 & 345.9 & -38.3 & 3.7000 & & & & & \\
\hline & 300 & 346.9 & -36.9 & 2.3636 & $802 \mathrm{~A}-6 \mathrm{IR}-1,95$ & 0 & 321.5 & -16.6 & 1.5727 \\
\hline & 350 & 347.7 & -35.3 & 1.6273 & & 0 & 126.6 & -32.3 & 26.8182 \\
\hline & 350 & 348.1 & -34.4 & 1.1818 & & 25 & 126.8 & -32.9 & 26.7273 \\
\hline & 450 & 349.1 & -33.1 & 0.9064 & & 50 & 127.1 & -33.7 & 23.1818 \\
\hline & 500 & 350.2 & -31.9 & 0.7345 & & 100 & 128.9 & 24.5 & 10.7273 \\
\hline & 550 & 350.7 & -31.2 & 0.5891 & & 150 & 127.6 & -33.5 & 6.9273 \\
\hline & 600 & 351.6 & -30.8 & 0.4864 & & 200 & 128.3 & -33.2 & 4.6636 \\
\hline & & & & & & 250 & 128.9 & -33.3 & 3.4545 \\
\hline \multirow{13}{*}{$802 \mathrm{~A}-59 \mathrm{R}-2,135$} & 0 & 46.5 & -5.1 & 4.6636 & & 300 & 129.4 & -32.5 & 2.6727 \\
\hline & 25 & 314.9 & -29.6 & 11.2727 & & 350 & 130.1 & -32.3 & 2.1273 \\
\hline & 50 & 314.1 & -27.9 & 9.6364 & & 400 & 130.7 & -32.1 & 1.7182 \\
\hline & 100 & 313.3 & -38.0 & 5.3727 & & 450 & 130.5 & -31.9 & 1.4000 \\
\hline & 150 & 315.9 & -31.4 & 1.8909 & & 500 & 131.0 & -32.4 & 1.1545 \\
\hline & 200 & 316.2 & -30.9 & 0.9727 & & 550 & 131.9 & -32.2 & 0.9727 \\
\hline & 250 & 316.9 & -29.3 & 0.5427 & & 600 & 131.7 & -31.5 & 0.7955 \\
\hline & 300 & 315.9 & -29.6 & 0.3482 & & 650 & 131.7 & -29.7 & 0.6791 \\
\hline & 300 & 317.0 & -28.5 & 0.2336 & & & & & \\
\hline & 400 & 317.3 & -27.2 & 0.1636 & $802 \mathrm{~A}-61 \mathrm{R}-1,145$ & 0 & 224.7 & 32.4 & 8.3909 \\
\hline & 450 & 309.7 & -25.3 & 0.1245 & & 0 & 115.8 & -30.9 & 17.7273 \\
\hline & 500 & 4.9 & -77.8 & 0.0392 & & 25 & 115.9 & -31.4 & 17.0909 \\
\hline & & & & & & 50 & 116.2 & -31.7 & 14.4545 \\
\hline \multirow{12}{*}{$802 \mathrm{~A}-59 \mathrm{R}-3,124$} & 0 & 90.8 & -65.3 & 10.0909 & & 100 & 116.6 & -31.5 & 6.4091 \\
\hline & 0 & 91.2 & -46.9 & 12.1818 & & 150 & 117.0 & -31.5 & 2.5909 \\
\hline & 25 & 90.8 & -47.0 & 12.0909 & & 200 & 117.8 & -30.5 & 1.2455 \\
\hline & 50 & 90.5 & -47.2 & 11.0909 & & 250 & 117.4 & -30.9 & 0.6873 \\
\hline & 100 & 90.2 & -46.8 & 5.9545 & & 300 & 118.4 & -30.5 & 0.4345 \\
\hline & 150 & 90.0 & -45.4 & 2.9364 & & 350 & 116.4 & -31.2 & 0.3009 \\
\hline & 200 & 89.8 & -44.6 & 1.7000 & & 400 & 117.7 & -32.1 & 0.2191 \\
\hline & 250 & 87.7 & -43.4 & 1.0909 & & 450 & 117.4 & -31.1 & 0.1709 \\
\hline & 300 & 89.4 & -42.3 & 0.7718 & & & & & \\
\hline & 350 & 90.8 & -42.0 & 0.5745 & $802 \mathrm{~A}-62 \mathrm{R}-1,92$ & 0 & 156.2 & -33.5 & 8.3455 \\
\hline & 400 & 90.0 & -41.6 & 0.4182 & & 25 & 154.7 & -34.2 & 6.5636 \\
\hline & & & & & & 50 & 154.4 & -36.3 & 4.3091 \\
\hline \multirow[t]{14}{*}{$802 \mathrm{~A}-60 \mathrm{R}-1,7$} & 0 & 260.9 & -2.8 & 2.3636 & & 100 & 153.2 & -39.1 & 1.7364 \\
\hline & 0 & 42.4 & -43.7 & 9.5455 & & 150 & 154.4 & -38.1 & 0.7682 \\
\hline & 25 & 42.7 & -44.6 & 9.4545 & & 200 & 153.5 & -37.6 & 0.4136 \\
\hline & 50 & 43.4 & -45.1 & 8.3182 & & 250 & 155.1 & -35.2 & 0.2282 \\
\hline & 100 & 43.4 & -45.4 & 4.2273 & & 300 & 154.0 & -33.7 & 0.1564 \\
\hline & 150 & 45.2 & -44.1 & 1.9182 & & 350 & 160.1 & -36.9 & 0.0945 \\
\hline & 200 & 45.7 & -42.4 & 1.0182 & & 400 & 158.3 & -46.0 & 0.0692 \\
\hline & 250 & 46.1 & -41.1 & 0.6145 & & 450 & 165.6 & -21.6 & 0.0714 \\
\hline & 300 & 45.9 & -39.8 & 0.4191 & & 500 & 152.5 & -35.4 & 0.0379 \\
\hline & 350 & 47.1 & -39.7 & 0.3018 & & & & & \\
\hline & 400 & 47.6 & -39.3 & 0.2236 & $802 \mathrm{~A}-62 \mathrm{R}-1,121$ & 0 & 289.2 & -20.0 & 4.6364 \\
\hline & 450 & 46.5 & -38.2 & 0.1727 & & 25 & 220.0 & -25.4 & 5.7455 \\
\hline & 500 & 49.1 & -40.6 & 0.1382 & & 50 & 220.8 & -30.1 & 4.2545 \\
\hline & & & & & & 100 & 222.3 & -32.6 & 2.1182 \\
\hline \multirow[t]{17}{*}{$802 \mathrm{~A}-60 \mathrm{R}-1,26$} & 0 & 119.7 & 22.6 & 6.4727 & & 150 & 222.9 & -32.7 & 1.0091 \\
\hline & 0 & 3.0 & -42.3 & 14.8182 & & 200 & 223.0 & -34.4 & 0.5445 \\
\hline & 25 & 3.1 & -43.2 & 14.4545 & & 250 & 222.1 & -32.4 & 0.3109 \\
\hline & 50 & 3.0 & -42.2 & 14.3636 & & 300 & 225.2 & -33.9 & 0.1973 \\
\hline & 100 & 3.7 & -44.0 & 9.3636 & & 350 & 218.3 & -35.6 & 0.1273 \\
\hline & 150 & 4.5 & -42.4 & 5.0455 & & 400 & 219.0 & -45.5 & 0.0982 \\
\hline & 200 & 5.3 & -39.4 & 2.9455 & & 450 & 203.7 & -31.3 & 0.0700 \\
\hline & 250 & 6.0 & -36.7 & 1.8455 & & 500 & 244.5 & -27.5 & 0.0555 \\
\hline & 300 & 6.5 & -34.4 & 1.2818 & & 550 & 242.2 & -53.4 & 0.0391 \\
\hline & 350 & 6.5 & -32.0 & 0.9273 & & & & & \\
\hline & 400 & 6.8 & -30.7 & 0.7164 & $802 \mathrm{~A}-62 \mathrm{R}-2,27$ & 0 & 228.1 & 34.6 & 1.9182 \\
\hline & 450 & 6.9 & -29.5 & 0.5709 & & 0 & 28.6 & -22.5 & 5.4182 \\
\hline & 500 & 7.9 & -28.5 & 0.4427 & & 25 & 29.9 & -32.7 & 4.5000 \\
\hline & 550 & 7.8 & -27.8 & 0.3600 & & 50 & 31.7 & -38.5 & 2.9727 \\
\hline & 600 & 8.3 & -27.7 & 0.2973 & & 100 & 32.9 & -41.9 & 1.3273 \\
\hline & 650 & 7.2 & -26.9 & 0.2445 & & 150 & 32.1 & -42.8 & 0.6045 \\
\hline & & & & & & 200 & 34.8 & -45.1 & 0.3336 \\
\hline \multirow[t]{8}{*}{$802 \mathrm{~A}-61 \mathrm{R}-1,70$} & 0 & 160.0 & -2.3 & 9.9091 & & 250 & 34.8 & -44.0 & 0.2000 \\
\hline & 0 & 284.3 & -34.4 & 28.8182 & & 300 & 31.4 & -44.3 & 0.1373 \\
\hline & 25 & 284.1 & -34.3 & 28.3636 & & 350 & 36.1 & -48.1 & 0.0792 \\
\hline & 50 & 284.7 & -34.5 & 25.0909 & & 400 & 25.7 & -47.2 & 0.0632 \\
\hline & 100 & 284.4 & -34.7 & 10.5455 & & 450 & 24.3 & -40.1 & 0.0516 \\
\hline & 150 & 285.1 & -35.2 & 4.0182 & & & & & \\
\hline & 200 & 285.5 & -35.8 & 1.8909 & $802 \mathrm{~A}-62 \mathrm{R}-2,64$ & 0 & 187.4 & 4.4 & 3.9727 \\
\hline & 250 & 286.7 & -36.2 & 1.0455 & & 0 & 321.4 & -28.4 & 10.2727 \\
\hline
\end{tabular}

Appendix (continued) 
B. P. WALLICK, M. B. STEINER

Appendix (continued).

\begin{tabular}{|c|c|c|c|c|}
\hline $\begin{array}{c}\text { Sample } \\
\text { (cm) }\end{array}$ & $\begin{array}{c}\text { AF step } \\
\text { (Oe) }\end{array}$ & $\begin{array}{l}\text { Declination } \\
\text { (degrees) }\end{array}$ & $\begin{array}{l}\text { Inclination } \\
\text { (degrees) }\end{array}$ & $\begin{array}{c}\text { Intensity } \\
(\mathrm{A} / \mathrm{m})\end{array}$ \\
\hline & 25 & 322.4 & -33.7 & 9.8182 \\
\hline & 50 & 322.1 & -36.7 & 8.2909 \\
\hline & 100 & 322.0 & -38.3 & 4.9455 \\
\hline & 150 & 321.7 & -38.6 & 2.4818 \\
\hline & 200 & 323.0 & -38.8 & 1.2818 \\
\hline & 250 & 321.5 & -38.6 & 0.6718 \\
\hline & 300 & 322.9 & -40.7 & 0.3909 \\
\hline & 350 & 326.2 & -38.5 & 0.2345 \\
\hline & 400 & 324.7 & -40.1 & 0.1500 \\
\hline & 450 & 325.0 & -43.1 & 0.1191 \\
\hline & 500 & 327.3 & -45.0 & 0.0812 \\
\hline \multirow[t]{13}{*}{$802 \mathrm{~A}-62 \mathrm{R}-3,23$} & 0 & 165.6 & 88.2 & 3.6455 \\
\hline & 0 & 218.6 & -34.3 & 11.2727 \\
\hline & 25 & 218.3 & -39.0 & 8.7545 \\
\hline & 50 & 218.2 & -41.7 & 5.1636 \\
\hline & 100 & 218.3 & -44.3 & 2.2000 \\
\hline & 150 & 217.6 & -44.4 & 1.2000 \\
\hline & 200 & 217.5 & -44.5 & 0.5982 \\
\hline & 250 & 216.5 & -43.5 & 0.4573 \\
\hline & 300 & 213.0 & -43.6 & 0.3164 \\
\hline & 350 & 217.2 & -44.6 & 0.2227 \\
\hline & 400 & 218.8 & -42.0 & 0.1655 \\
\hline & 450 & 205.6 & -40.9 & 0.1373 \\
\hline & 500 & 208.8 & -49.0 & 0.1109 \\
\hline
\end{tabular}

